\title{
Perspectives: University of Haifa Israel Studies
}

\author{
Gabriel Mayer \\ University of Haifa. Israel
}

\begin{abstract}
University of Haifa International School offers an MA in Israel Studies over an approximately one-year period. As a final exam exercise, the student is asked to write an essay describing his/her interaction with the Israel national narrative as taught in courses and experienced during field trips and personal interactions with the surrounding land and landscapes, museums, archeological sites and living "inside the Judaic calendar" for the whole year. In effect, the student's encounters may be summed up as an interface with memoryscape. The following is one student's interpretation of this assignment. The scope of this work is an exploration of the Israel narrative, as it was shaped from the early settlement years into the modern and complex State of Israel. My ambition is to trace the early settlement periods, let's say counting from the late 1880's, through the development of Eretz Israel into the Jewish homeland, a concept that seemed like the story of the "impossible dream." Over the course of my studies, we were presented with many "up close" views of the historical markers that are present in this narrative. No textbook reading alone can equal the experience a student has when history can be seen from a local, palpable and "up-front" viewpoint.
\end{abstract}

\section{Ben Gurion's Mamlakhtiyut:}

To commence the story, we will start in the middle. At first glance, the term Mamlakhtiyut appears quite confusing since no English equivalent exists for it. Hebrew-English dictionaries translate the term as "statehood" or "sovereignty," with the adjective mamlakhti rendered as "officially of the state." ${ }^{1}$ Why this is of great importance-even though Ben Gurion struggled with the exact definition-is the concept that he was attempting to embrace and promulgate. He was seeking to define a term, which would inclusively inscribe the very concept of the nationhood he sought to establish. Only the future would be capable of measuring the degree of success and if we glance at a book written nearly two generations after Ben-Gurion first came up with the notion, we realize that the Sabra, a term used to describe those who were born post statehood was the very embodiment of what at one time seemed as phantasy. ${ }^{2}$ Professor Oz Almog was able to give precision to the term and the Sabra became both a physical and theoretical entity.

Ben-Gurion's was perpetually obsessed with the notion of state building and realized early on that a coherent message was necessary to shepherd a highly mixed population toward a functional state. He knew but too well the immeasurable differences in the political inclinations of the populace and his own socialist leaning attitudes were in great conflict with many. An observation made during his funeral eulogy explains it best, "The funeral, then, was a formative event in the history of the state. The state bade farewell to its foremost leader, and in so doing created a sacred national site, a destination for secular-national pilgrimage. However, in achieving this, the state established a symbolic center that was far removed from the political,

1 Nir Kedar, "Ben-Gurion's Mamlakhtiyut: Etymological and Theoretical Roots," Israel Studies 7, no. 3 (2002).

${ }^{2}$ Oz Almog, The Sabra: The Creation of the New Jew (Univ of California Press, 2000). 
social, and demographic centers. Ben Gurion's grave is a central symbol of Israeli Mamlakhtiyut, but at the same time it gazes with perpetual criticism at Israel"3

While Ben-Gurion may be the "father" of the modern state it was Zionism as ideology that first laid the groundwork. Zionism was, in part, the basic principle of the Jewish homeland or Eretz Israel, but even this does not conclusively describe the early settlement periods and the rag tag immigrants that began arriving in Palestine in the late 1800's. ${ }^{4}$

\section{EXPERIENTIAL LEARNING AND PERFORMATIVITY}

I chose to begin with the preceding as a sort of self-proclaimed midpoint in the tracing of the Israel narrative. But now I wish to digress from the main story and offer a view into the exceptional nature of the Israel Studies and Jewish Studies programs. As we know these two programs share many courses. During the 2016 fall semester I had the opportunity to take a course with Professor Amos Morris-Reich. His course aimed to introduce the students to the notion of Performativity. This topic may be said to ascribe a certain interaction between the audience and the venue of interest, be it the arts, or the historical museum, or any other form of interactivity formed between the presenter and the audience. The incubation of what has now grown into a disciplinary academic practice had its beginnings rooted in the revolutionary linguistic philosophical approach of J.L. Austin whose series of William James Lectures at Harvard University during the 1970's launched a whole new approach to language and later on enveloping many other disciplines. ${ }^{5}$ The approach of a Performative viewpoint spread to many fields. It is the underlying principle utilized by the well-known historian and museologist, Barbara Kirshenblatt-Gimblett. ${ }^{6}$ Her best-known work, "Destination Culture" had drawn wide acclaim for projecting the Performative aspects of many historical discourses toward a better understanding. Performativity has moved into the dynamics of the disciplines of teaching, where it was reshaped into what we now call experiential learning. Many well known Israeli academicians have studied this experiential approach when dissecting the teaching benefits of Taglit $^{7}$ and similar programs. ${ }^{8}$

Indeed the two Haifa University MA programs I just mentioned make use of experiential learning in approximately $25 \%$ of teaching time as evidenced by the multiple field trips and some classes wholly devoted to geographic encounters with the subject matter. ${ }^{9}$

Now, as I return to the main body of this work, we shall have a better viewpoint of the palpable nature of learning the students get in studying the Israel narrative.

\footnotetext{
${ }^{3}$ Michael Feige and David Journal of Israeli History Ohana, "Funeral at the Edge of a Cliff: Israel Bids Farewell to David Ben-Gurion," 31, no. 2 (2012): p. 249-51.

${ }^{4}$ Derek Jonathan Penslar, Zionism and Technocracy: The Engineering of Jewish Settlement in Palestine, 1870-1918 (Indiana University Press, 1991).

5 John Langshaw Austin, How to Do Things with Words (Oxford university press, 1975).

${ }^{6}$ Barbara Kirshenblatt-Gimblett, Destination Culture: Tourism, Museums, and Heritage (Univ of California Press, 1998).

${ }^{7}$ Leonard Saxe, Theodore Sasson, and Shahar Hecht, "Taglit-Birthright Israel: Impact on Jewish Identity, Peoplehood, and Connection to Israel," (2006).

8 Zvi Bekerman, Nicholas C Burbules, and Diana Silberman-Keller, Learning in Places: The Informal Education Reader, vol. 249 (Peter Lang, 2006).

${ }_{9}^{9}$ Gabriel Mayer, "A Study of Experiential Learning Features in Two Departments at Haifa University International School: Jewish Studies and Israel Studies," Advances in Social Sciences Research Journal 5, no. 4 (2018).
} 


\section{The Aliyot and populating Palestine:}

While we can all agree that the vast majority of early Palestinian settlers were Jewish, the nature of their "Jewishness" as well as their political makeup was a polyglot of humanity.

Yet they had to cooperate to some degree to survive. They lived in groups forming Moshavs and Kibbutzes and struggled daily to eke out a survival. But their Jewish roots coalesced accidentally and often by fortuitous incidents. ${ }^{10}$ The story of the ancient synagogue of Beth Alpha, later excavated by the father of Israeli archeology ${ }^{11} \mathrm{E}$. Sukenik, offers an imperfect example of what occurred during such times. ".12 If we step back and look at all the characters or players in the foregoing, we see a group of Zionist idealists who were striving for similar political goals but their archeological efforts were guided more by a uniform Jewish nationalism common in Europe, the US, and Palestine, and differing from that which became institutionalized in statism upon the formation of the state of Israel in $1948 .{ }^{13}$ Most telling perhaps would be a closer examination of the young settlers who first came upon the remnants of the $5^{\text {th }}$ century synagogue excavated by Sukenik. They were early Zionist pioneers of Beit Alpha, a communal settlement in the Esdraelon Valley. The settlement was founded in the early Twenties by young men and women belong to the socialist youth movement Hashomer Hatzair (Young Guard). They subscribed to a bizarre combination of utopian Marxism, Freudian psychoanalysis, and the then fashionable German Jugendkultur, with its Romantic worship of nature, cult of eroticism, and disdain for bourgeois values. In December 1928, some of them were digging an irrigation channel and suddenly struck the brilliantly colored mosaic of a sixth century Jewish synagogue. Their first reaction was to keep the discovery secret, and possibly cover it up again - a natural impulse, perhaps, that field archaeologists often encounter. The main concern, after all, had been to dig an irrigation channel. The unexpected discovery complicated this task and threatened to hold it up, perhaps indefinitely.

But there was more to it: an anti-religion attitude. The young kibbutzniks, full of the fervor of Russian radicalism, had only a year or two earlier come out of Eastern Europe with-as the saying went at the time-"no clothes, but with copies of Das Kapital and Freud's Interpretation of Dreams in their knapsacks." A few were still teen-agers. Others were in open rebellion against their Orthodox religious fathers. Some had actually run away from home to help build socialism and create the "new Jew" in the historic land of his forefathers: a utopian community not unlike those of the late 1960s in which their identity would be redefined and based on socialism and love. Religion was the opium of the people. For this reason alone, it might be best if the synagogue mosaic were covered up again. Others argued that the mosaic was not necessarily religious but rather political, a Zionist monument. It was important, so the argument went, to uphold every archaeological remnant that testified to the Jewish presence in the land, and confirmed the legitimacy of the Zionist claim. A debate took place. The conservationist view prevailed over the iconoclastic." 14 The fact that these were Jewish efforts, sans the imprint of Zionist statism, did not go unnoticed by the world press such as the NYT. A February 7, 1928 article begins with, "Recent excavations in Palestine have proved that there is

\footnotetext{
10 Yossi Ben-Artzi, "Imitation or Original? Shaping the Cultural Landscape of Pioneer Jewish Settlement in Eretz Israel (1882-1914)," Journal of Historical Geography 22, no. 3 (1996).

11 Eleazar Lipa Sukenik, The Ancient Synagogue of Beth Alpha: An Account of the Excavations Conducted on Behalf of the Hebrew University, Jerusalem (1932).

12 Amos Elon, "Politics and Archaeology," JOURNAL FOR THE STUDY OF THE OLD TESTAMENT SUPPLEMENT SERIES (1997): pp. 33-36.

13 Zohar Segev, "Universalism, Ethnic Identity and Divided Nationality: Abba Hillel Silver's Role in American Zionism," Journal of Jewish studies 63, no. 1 (2012): pp. 109-11.

14 Elon, "Politics and Archaeology," p. 36.
} 
not a flaw in the biblical narrative of the campaigns of Joshua, and they can now be traced with absolute topographical accuracy." 15

As it turns out, archeology would form the very bond between Jewishness, Judaism and settlement sentiments. ${ }^{16}$ As time went along, archeological excavations filled in the narrative lines. While the story of the Maccabean Revolt was the first of Israel's festivals to be documented in written history ${ }^{17}$ and now known as the Chanukah story. Future writers such as Yigael Yadin would fill in the stories ${ }^{18}$ and elevate to heroic status sites at Tel Hador ${ }^{19}$ and Masada. ${ }^{20}$

\section{ZIONISM, A FOUNDATIONAL NARRATIVE}

Bypassing the tremendous sociopolitical impact that Zionism produced, we can see that it was also a formative element of the national ethos. To commence this analysis I wish to report on two episodes occurring in the Yeshuv in the 1920s. In one we look at the development of the Zionization of everyday life, specifically at the time when a Zionist periodization of history was evolving. During the period between the First and Second Aliya, oddly enough, there was no numbering system or distinction between immigrant groups. ${ }^{21}$ That there should even be such a system, called Zionist Periodization, has become questionable, especially since Gur Alroey's research has demonstrated a number of smaller distinct groups throughout the settlement period. More recently, Hizky Shoham has examined the genesis of Zionist Periodization and has produced some surprising results .22 It may come as a surprise, but the first named "wave" was the Third Aliya; however the numbered title had a completely different origin than what is customarily understood. Shoham is able to attribute the periodization phenomena to events surrounding the Third Aliyah. Apparently a confluence of written material by several influential religious writers of the time led to the widespread belief that the Third Aliyah was about to occur! But this was not the third Aliyah that we know today; rather it was third following the First Aliyah from the biblical days of Zerubavel and the Second, about 80 years later, from Nehemiah. So widespread was this belief, for at least a brief period of time, which rumors ran wild and the arrival of the Ruslan - a ship sailing from Odessa in December of 1919 - was perceived by some as the start of this much anticipated event. 8].Subsequent to this, a few years later, what is now the familiar nominalization became widespread.

From the very earliest period of the settlement movement, the Jews were constantly under attack. Thus as far back as 1909 organizing military defenses became a primary goal and produced the HaShomer, which was a foundational aspect of defensive organizing. ${ }^{23}$

\footnotetext{
15 Digital Archives NYT, "Ruins of Palestine Bear out the Bible," New York Times 1928,February 7.

${ }^{16}$ A \& S Bar-Am, "It's All About the Roots," The Times of Israel 2013, February.

17 Lesli Koppelman Ross, Celebrate!: The Complete Jewish Holidays Handbook (Jason Aronson, Incorporated, 2000).

18 George M The Biblical Archaeologist Landes, "The Material Civilization of the Ammonites," 24, no. 3 (1961).

19 Moshe Kochavi and E Yadin, "Hadar, Tel," The New Encyclopedia of Archaeological Excavations in the Holy Land 5 (2008).

20 Yigael Yadin, Masada: Herod's Fortress and the Zealots' Last Stand (Sphere Books, 1973).

${ }^{21}$ Gur Alroey, "Immigrants: Jewish Immigration to Palestine in the Early Twentieth Century," Jerusalem: Yad Yitzchak Ben Zvi (2004).

22 Hizky Shoham, "From" Great History" to" Small History": The Genesis of the Zionist Periodization," israel studies 18, no. 1 (2013).

${ }^{23}$ Aviva Tel Aviv: Am Oved Halamish, "Meir Ya'ari: Biografiyah Kibutzit, Hamishim Ha-Shanim Ha-Rishonot, 18971947 [Meir Ya'ari: A Collective Biography, the First Fifty Years, 1897-1947]," (2009).
} 
By the 1930's the Hashomer began to evolve and reorganize until the final metamorphosis product, the Haganah was established. This organization, which initially was preoccupied with anti British resistance, also evolved into what would later become the IDF. ${ }^{24}$

The Haganah was initially preoccupied by defense against constant attacks from Arab neighbors as well as anti British maneuvers and it was slowly becoming a highly organized fighting force. This, in part, was due to the high caliber of recruits and their development of superior tactics. ${ }^{25}$

\section{War of Independence:}

Attacked by every single Arab nation, the 1948 war was one of survival in the most literal sense! Coming only a few years after the Shoah (many survivors fought in this war), there was no doubt in anyone's mind that the final intent was not just a land grab, but also the annihilation of Jews in Israel. At the commencement, a rag tag group of men and women, most entirely inexperienced, and a few having come through the Haganah, were pitted against the well-armed armies of many nations. ${ }^{26}$ But with surprising victories everywhere-though not without the loss of life- the Israeli fighting forces were soon dealing a rout to all enemies. Within months the UN, along with the US ambassador Ralph Bunch was imploring the Israelis to cease their attack on the now retreating Arabs. ${ }^{27}$ Ben-Gurion was now faced with a decision, to go all out and gain maximum land or to stop and concentrate on nation building. The final decision to stop was brought about by a most useless, surprising, and unexpected incident. One of the main UN negotiators was Count Bernadotte of Sweden. A mainly useless, vapid and selfaggrandizing political figure, much of the partition negotiations were left in his hand. On September 17, 1948, while ensconced in Jerusalem hotel, he along with the French military advisor, Colonel Andre Serot, were assassinated by members of the Stern Gang ${ }^{28}$ who shot both as they were riding off in their automobile. ${ }^{29}$ This then became the cause of a scandal that seemed to threaten the entire existence of the State of Israel and the negotiations quickly folded thereafter.

\section{THE 1950'S AND THE 1960'S}

During the phase following the highly successful War of Independence, the nation of Israel grew at a dizzying space. Along with growth came a renewed enthusiasm for archeology and the explorations of archeological sites became a favorite weekend sport. ${ }^{30}$ Perhaps as many as $30 \%$ of the populace was scouring the countryside on any given weekend and amateur archeology clubs abounded everywhere. During these times the Israelis began to identify with their land and personhood merged with nationhood. The heroes of Masada, the Maccabees, along with Samson, Gideon and other Biblical figures were interwoven with the visible land and the mythological roots became part of the national narratives. ${ }^{31}$ With these ideologies as a

\footnotetext{
24 Yoav Yad Ben Tzvi Gelber, "Nucleus for a Standing Army," (1986).

25 Neil A Silberman, "A Prophet from Amongst You: The Life of Yigael Yadin, Soldier, Scholar, and Mythmaker of Modern Israel," (1996): pp. 57-85.

${ }^{26}$ Uri Milstein, History of the War of Independence: The First Month, vol. 2 (University Press of America, 1996).

${ }_{27}$ Avi Shlaim, "Documents on the Foreign Policy of Israel. Vol. 3: Armistice Negotiations with the Arab States, December 1948-July 1949," (Wiley, 1984).

28 Lehi, or as pejoratively called the Stern Gang, were a runaway organization that was never in sync with the IDF and often clashed with it. Joseph Heller, The Stern Gang: Ideology, Politics and Terror, 1940-1949 (Routledge, 2012).

${ }^{29}$ Silberman, "A Prophet from Amongst You: The Life of Yigael Yadin, Soldier, Scholar, and Mythmaker of Modern Israel." P. 149

${ }^{30}$ Neil Asher Silberman and David B Small, The Archaeology of Israel: Constructing the Past, Interpreting the Present (A\&C Black, 1997), pp. 18-41.

31 Joseph Campbell, Creative Mythology (Secker \& Warburg, 1968).
} 
foundational system of beliefs, along with the recent armed victories during the War of Independence, the IDF was slowly assimilated into the national mythology. This belief system would soon be tested in the wars to come.

\section{Modern Warfare:}

The War of 1967 was a turning point as far as proving the efficiency of the IDF. ${ }^{32}$

In the months prior to June 1967, tensions became dangerously heightened. Israel reiterated its post-1956 position that the closure of the Straits of Tiran to Israeli shipping would be a cause for war (a casus belli). In May Egyptian President Gamal Abdel Nasser announced that the straits would be closed to Israeli vessels and then mobilized its Egyptian forces along its border with Israel. On 5 June, Israel launched what it claimed were a series of preemptive airstrikes against Egyptian airfields. Which side caused the war is one of a number of controversies relating to the conflict.

In six short days, the IDF annihilated the armed forces of Egypt and the Israeli Air Force became the dominant figure in the sky for all future challenges. The map of the Middle East was redrawn entirely and the Jews now controlled Jerusalem. The Kotel, the most revered of historical and religious sentiments now belonged to Israel. This was the "6 Day War" and no longer was there any doubt as to the superiority of the IDF. The Yom Kippur War, Ramadan War, or October War (Hebrew: הכיפורים יום מלחמת, Milhemet Yom HaKipurim, or יום מלחמת כיפור, Milhemet Yom Kipur, also known as the 1973 Arab-Israeli War, was a war fought from October 6 to 25, 1973, by a coalition of Arab states led by Egypt and Syria against Israel. The war took place mostly in Sinai and the Golan-occupied by Israel during the 1967 Six-Day War-with some fighting in African Egypt and northern Israel. [56][57] Egypt's initial war objective was to use its military to seize a foothold on the east bank of the Suez Canal and use this to negotiate the return of the rest of Sinai.

The war began when the Arab coalition launched a joint surprise attack on Israeli positions, on Yom Kippur, the holiest day in Judaism, which also occurred that year during the Muslim holy month of Ramadan, Egyptian and Syrian forces crossed ceasefire lines to enter the Sinai Peninsula and the Golan Heights, respectively. Both the United States and the Soviet Union initiated massive resupply efforts to their respective allies during the war, and this led to a near-confrontation between the two nuclear superpowers. It was launched on the holiest of Hebrew holidays and the Arabs' intentions were to catch the IDF during an extremely surprising moment. While the surprise existed, the enemies did not foresee the fact that with armed soldiers being at home with their families, the mobilization of the armies was made much faster. Caught by surprise at first, the IDF was quick to counter-attack the seam between two Egyptian forces, then crossed the Suez Canal into Egypt and then began a slow advance toward the City of Suez. The Israelis had improved their positions and completed the encirclement of Egypt's Third Army as well as the City of Suez, At this point Israel held an upper hand and negotiations led by the United States and the Soviet Union. The resulting entente and peace negations had far reaching effects. The population of Israel felt a great loss of life and frustrations against the government rose. Golda Meir, the Prime Minister at the time was blamed for much of the losses and she resigned shortly thereafter. On the other hand the

32 Michael B Oren, Six Days of War: June 1967 and the Making of the Modern Middle East (Presidio Press, 2017). 
balance of power in the Middle East began a shift, which saw the Soviet Union coming out on the short end of the stick as compared with the USA. ${ }^{33}$

In the aftermath, Israeli technology exploded on the scene with force and enthusiasm, which would gain it the future nickname of the start up nation. ${ }^{34}$ Israel would soon be making technological advances that would rival and exceed the majority of global powers. During the second Lebanon War of 2006, while loss of life was a tragic consequence, the technical superiority went unchallenged. The Iron Dome was developed by Israel with close cooperation of the United States and it has increasingly become a mighty deterrent and a successful defense concept. ${ }^{35}$ Israel began developing spying and security inventions that began usage worldwide. ${ }^{36}$ Israel was identified as the start up nation and the global security expert. ${ }^{37}$ These technological advances were built on resourcefulness and human intelligence, but they were backed by the Israeli myths arising during initial statehood. Nationhood and personhood were now a highly successive amalgamation, which was tested and proved successful in most military challenges. ${ }^{38}$ The IDF had come of age as a mythological wonder and a scientific miracle. ${ }^{39}$

\section{The Variables:}

Israel's political system is a complex and difficult enterprise. It is beyond the scope of my discussion to go into any details. Suffice it to say that the state has weathered many changes across a political landscape that is always moving. Elements that cannot be ignored are the farreaching consequences of Jabotinsky's Revisionism and it's rebirth under Likud ${ }^{40}$ Led by Menachem Begin's surprise victory in 1977, the Likud ascendancy would forever change the Israel polity and as a result the society's function as a whole. ${ }^{41}$ Here was the moment when the old socialist instincts, a foundational element in early statehood, were exchanged into a more modern capitalistic society.

\section{Life in Israel:}

The effects of living in a society where the annual calendar and holidays and festivals all revolve around the Biblical intents of Judaism are unmistakable. One can feel the pulse and colorful pageantry of the Biblical Jewish life on the everyday streets, the holidays and in the homes. Israel revolves around its ancient roots. Mythology, Judaism and the state, along with everyday life are part and parcel of the same package. For a student of Israel studies nothing

\footnotetext{
33 Viktor Levonovich Israelian, Inside the Kremlin During the Yom Kippur War (Pennsylvania State University Press University Park, 1995). And Martin Van Creveld, Military Lessons of the Yom Kippur War: Historical Perspectives (Sage Publications (CA), 1975).

34 Tamar Almor, "Israel-Start up Nation." And Jerome S Engel and Itxaso \%J California Management Review delPalacio, "Global Clusters of Innovation: The Case of Israel and Silicon Valley," 53, no. 2 (2011).

35 Yiftah SJ Shapir, "Lessons from the Iron Dome," Military

Strategic Affairs 5, no. 1 (2013).

${ }^{36}$ Erella Grassiani, "Between Security and Military Identities: The Case of Israeli Security Experts," Security dialogue 49, no. 1-2 (2018).

3737 Dmitry Adamsky, "The Israeli Odyssey toward Its National Cyber Security Strategy," The Washington Quarterly 40, no. 2 (2017). And Gil Baram Isaac Ben-Israel, "The Academic Reserve: Israel's Fast Track to HighTech Success."

${ }^{38}$ Frank G Orbis Hoffman, "Complex Irregular Warfare: The Next Revolution in Military Affairs," 50, no. 3 (2006).

39 Jeffrey Carr, Inside Cyber Warfare: Mapping the Cyber Underworld (" O'Reilly Media, Inc.", 2011).

40 Eran Kaplan, The Jewish Radical Right: Revisionist Zionism and Its Ideological Legacy (Univ of Wisconsin Press, 2005), pasim.

41 Yaffa Moshkovich, "The Effects of Electoral Defeat and Victory on Internal Power Struggles in the Israeli Likud Party," MERIA Journal 15, no. 2 (2011).
} 
can compare to this outside encirclement of the campus by the reality of the state of Israel. The experience is profound, inimitable, and most instructional.

\section{References}

Adamsky, Dmitry "The Israeli Odyssey toward Its National Cyber Security Strategy." The Washington Quarterly 40, no. 2 (2017): 113-27.

Almog, Oz. The Sabra: The Creation of the New Jew. Univ of California Press, 2000.

Almor, Tamar. "Israel-Start up Nation."

Alroey, Gur. "Immigrants: Jewish Immigration to Palestine in the Early Twentieth Century." Jerusalem: Yad Yitzchak Ben Zvi (2004).

Austin, John Langshaw. How to Do Things with Words. Oxford university press, 1975.

Bar-Am, A \& S. "It's All About the Roots." The Times of Israel, 2013, February.

Bekerman, Zvi, Nicholas C Burbules, and Diana Silberman-Keller. Learning in Places: The Informal Education Reader. Vol. 249: Peter Lang, 2006.

Ben-Artzi, Yossi. "Imitation or Original? Shaping the Cultural Landscape of Pioneer Jewish Settlement in Eretz Israel (1882-1914)." Journal of Historical Geography 22, no. 3 (1996): 308-26.

Ben-Israel, Gil Baram Isaac. "The Academic Reserve: Israel's Fast Track to High-Tech Success."

Campbell, Joseph. Creative Mythology. Secker \& Warburg, 1968.

Carr, Jeffrey. Inside Cyber Warfare: Mapping the Cyber Underworld. " O'Reilly Media, Inc.", 2011.

Elon, Amos. "Politics and Archaeology." JOURNAL FOR THE STUDY OF THE OLD TESTAMENT SUPPLEMENT SERIES (1997): 34-47.

Engel, Jerome S, and Itxaso \%J California Management Review del-Palacio. "Global Clusters of Innovation: The Case of Israel and Silicon Valley." 53, no. 2 (2011): 27-49.

Feige, Michael, and David Journal of Israeli History Ohana. "Funeral at the Edge of a Cliff: Israel Bids Farewell to David Ben-Gurion." 31, no. 2 (2012): 249-81.

Gelber, Yoav Yad Ben Tzvi. "Nucleus for a Standing Army." (1986).

Grassiani, Erella "Between Security and Military Identities: The Case of Israeli Security Experts." Security dialogue 49, no. 1-2 (2018): 83-95.

Halamish, Aviva Tel Aviv: Am Oved. "Meir Ya'ari: Biografiyah Kibutzit, Hamishim Ha-Shanim Ha-Rishonot, 18971947 [Meir Ya'ari: A Collective Biography, the First Fifty Years, 1897-1947]." (2009).

Heller, Joseph. The Stern Gang: Ideology, Politics and Terror, 1940-1949. Routledge, 2012.

Hoffman, Frank G Orbis. "Complex Irregular Warfare: The Next Revolution in Military Affairs." 50, no. 3 (2006): 395-411.

Israelian, Viktor Levonovich. Inside the Kremlin During the Yom Kippur War. Pennsylvania State University Press University Park, 1995.

Kaplan, Eran. The Jewish Radical Right: Revisionist Zionism and Its Ideological Legacy. Univ of Wisconsin Press, 2005.

Kedar, Nir. "Ben-Gurion's Mamlakhtiyut: Etymological and Theoretical Roots." Israel Studies 7, no. 3 (2002): 117 33.

Kirshenblatt-Gimblett, Barbara. Destination Culture: Tourism, Museums, and Heritage. Univ of California Press, 1998.

Kochavi, Moshe, and E Yadin. "Hadar, Tel." The New Encyclopedia of Archaeological Excavations in the Holy Land 5 (2008): 1756-57.

Landes, George M The Biblical Archaeologist. "The Material Civilization of the Ammonites." 24, no. 3 (1961): 6686.

Mayer, Gabriel "A Study of Experiential Learning Features in Two Departments at Haifa University International School: Jewish Studies and Israel Studies." Advances in Social Sciences Research Journal 5, no. 4 (2018).

Milstein, Uri. History of the War of Independence: The First Month. Vol. 2: University Press of America, 1996. 
Moshkovich, Yaffa "The Effects of Electoral Defeat and Victory on Internal Power Struggles in the Israeli Likud Party." MERIA Journal 15, no. 2 (2011).

NYT, Digital Archives. "Ruins of Palestine Bear out the Bible." New York Times, 1928,February 7.

Oren, Michael B. Six Days of War: June 1967 and the Making of the Modern Middle East. Presidio Press, 2017.

Penslar, Derek Jonathan. Zionism and Technocracy: The Engineering of Jewish Settlement in Palestine, 1870-1918. Indiana University Press, 1991.

Ross, Lesli Koppelman. Celebrate!: The Complete Jewish Holidays Handbook. Jason Aronson, Incorporated, 2000.

Saxe, Leonard, Theodore Sasson, and Shahar Hecht. "Taglit-Birthright Israel: Impact on Jewish Identity, Peoplehood, and Connection to Israel." (2006).

Segev, Zohar. "Universalism, Ethnic Identity and Divided Nationality: Abba Hillel Silver's Role in American Zionism." Journal of Jewish studies 63, no. 1 (2012): 105-26.

Shapir, Yiftah SJ "Lessons from the Iron Dome." Military

Strategic Affairs 5, no. 1 (2013): 81-94.

Shlaim, Avi. "Documents on the Foreign Policy of Israel. Vol. 3: Armistice Negotiations with the Arab States, December 1948-July 1949." Wiley, 1984.

Shoham, Hizky. "From" Great History" to" Small History": The Genesis of the Zionist Periodization." israel studies 18, no. 1 (2013): 31-55.

Silberman, Neil A. "A Prophet from Amongst You: The Life of Yigael Yadin, Soldier, Scholar, and Mythmaker of Modern Israel." (1996).

Silberman, Neil Asher, and David B Small. The Archaeology of Israel: Constructing the Past, Interpreting the Present. A\&C Black, 1997.

Sukenik, Eleazar Lipa. The Ancient Synagogue of Beth Alpha: An Account of the Excavations Conducted on Behalf of the Hebrew University, Jerusalem. 1932.

Van Creveld, Martin. Military Lessons of the Yom Kippur War: Historical Perspectives. Sage Publications (CA), 1975. Yadin, Yigael. Masada: Herod's Fortress and the Zealots' Last Stand. Sphere Books, 1973. 